\title{
Algunos datos y consideraciones sobre el origen y los objetivos de Hermenéutica Intercultural
}

Ramón Sepúlveda Leiva'

\section{Inicios de Hermenéutica Intercultural como Boletín de Filosofía}

La revista Hermenéutica Intercultural es continuadora del Boletín de Filosofía del IPES Blas Cañas (predecesor de la Universidad Católica Silva Henríquez), que fue publicado por primera vez en el año 1987.

Su objetivo inicial era: "Entregar el primer Boletín de Filosofía orientado a los docentes de esta disciplina" para aportarles elementos de reflexión. Por esta razón, los primeros números fueron enviados a diversos colegios católicos de Santiago y Provincia.

Respecto de la orientación temática de los primeros números, la publicación se planteaba en un contexto de crisis moral, política, social y económica del país, frente al cual era fundamental la reflexión filosófica y antropológica. Todo esto con el fin de buscar pistas para una convivencia humana solidaria, fraterna y justa, según el primer director: Jaime Caiceo. Editorialmente, se señala de modo textual: "Este Boletín de Filosofía $\mathrm{N}^{\circ} 1$ se centra sobre la reflexión antropológica y ética en el contexto del Humanismo Cristiano".

Esta orientación es asumida por los primeros articulistas, y la portada alude a ello con las imágenes de Santo Tomás de Aquino, Jacques Maritain, Manuel Mounier y Juan Pablo II.

1 Chileno, profesor de filosofía, exdirector de la Escuela de Filosofía de la Universidad Católica Silva Henríquez, exeditor del Boletín de Filosofía y ex director de Hermenéutica Intercultural. 


\section{Evolución del Boletín}

A partir del N ${ }^{\circ} 6$ del año 1992, cuando ya el IPES Blas Cañas ha pasado a ser Universidad Católica Blas Cañas (UCBC) y bajo un nuevo director (Ricardo Salas Astraín), el Boletín abre sus páginas a académicos de otras universidades, incorporando temáticas de mayor amplitud que muestran la pluralidad de las inquietudes filosóficas. Ya en el $\mathrm{N}^{\circ}$ 8 aparecen los temas hermenéuticos, que marcarán paulatinamente un cambio en la orientación inicial del Boletín.

El Boletín № 9 de 1997 y 1998, publicado en tres volúmenes, constituye la primera edición de Pensamiento Filosófico Latinoamericano, libro que en 2005 se reedita y amplía en tres tomos. En este Boletín aportan sus visiones disciplinarias y sus diagnósticos, diversos e importantes especialistas de la cultura latinoamericana.

En el Boletín $\mathrm{N}^{\circ} 10$ se abordan temas de filosofía de la religión, y en el № 11 temas filosóficos diversos, priorizando la filosofía de la cultura. Ambos números son ya publicados bajo el alero de la actual Universidad Católica Silva Henríquez.

\section{Nueva orientación y cambio del nombre al de Hermenéutica Intercultural}

La nueva orientación de la revista se percibe al cambiar su nombre al de Hermenéutica Intercultural en el № 12 de 2002 y 2003: "En el espíritu de diálogo y de comunicación con las tradiciones culturales diversas a la que nos invita la filosofía gadameriana y la hermenéutica filosófica actual, este Boletín de Filosofía cambia hoy de nombre. Esto como testimonio de una forma de articular su apertura a los diferentes saberes culturales y a la multiplicidad de perspectivas y tradiciones filosóficas. Así, desde este número se llamará Hermenéutica Intercultural: Revista de Filosofía. Además, en este número se comienza a hacer la presentación bilingüe de los resúmenes o "abstracts" de los artículos (primero en francés y luego en inglés).

En este contexto, se da una ampliación de los objetivos, pues los Nos 10 y 11 habían reconocido editorialmente los objetivos iniciales del 
Boletín. Sin embargo, a partir del $N^{\circ} 12$, se indica que Hermenéutica Intercultural es una "Publicación destinada a los profesores de filosofía de Enseñanza Media, a los académicos y alumnos de filosofía de diversas partes del país" que "quisieran apoyar el proceso de consolidación de la filosofía y de la ética en la Enseñanza Media". Y esta ampliación queda en evidencia al señalarse también la "búsqueda de contactos filosóficos entre académicos de diferentes universidades que intentan participar reflexivamente en el discernimiento de los procesos culturales y éticos de nuestro país".

\section{Personas e hitos significativos en la historia de la revista}

Los directores han sido los responsables de la línea editorial del Boletín, por el cargo de gestión que les corresponde dentro de la Universidad. Es importante destacar a dos de ellos en su trayectoria: el Dr. Jaime Caiceo Escudero, que lideró la idea del Boletín y la concretó, siendo su fundador en 1987. Y el Dr. Ricardo Salas Astraín, quien desde el año 1992 amplió su horizonte, elevando su nivel académico y de apertura, consolidando la revista como una publicación importante dentro del ámbito filosófico en Chile.

A partir del № 12 de 2002 y 2003, cuando me correspondió hacerme cargo de la Dirección dejando de ser su editor, los editores posteriores han sido clave para la continuidad y mejoramiento de la publicación ya denominada Hermenéutica Intercultural. Menciono al Dr. Jaime Retamal, al Dr. Luis Uribe, al Mg. Martín Ríos, al Mg. Antonio Freire, y a la Dra. Mariela Avila, actual editora. Fue director de la revista el Dr. Pablo Solórzano, y en este momento la Dirección recae en el Mg. Iván Briceño. Todos ellos, con su trabajo proactivo, dedicado y minucioso, han hecho posible el avance y crecimiento de Hermenéutica Intercultural.

En la editorial del $N^{\circ} 16$ de 2007, al cumplirse los 20 años de la revista, se hace un recuerdo y reconocimiento a quienes han hecho posible su mantención y desarrollo. 
Las noticias breves iniciadas en el $N^{\circ} 6$ de 1992, dan cuenta de las muchas actividades académicas y estudiantiles de la coordinación y luego de la carrera de Pedagogía en Filosofía. Entre otras se destacan seminarios y jornadas de filosofía, concursos nacionales de ensayos filosóficos para estudiantes de Educación Media, reuniones filosóficas estudiantiles interuniversitarias con sus publicaciones, encuentros filosóficos de estudiantes secundarios (EFES), publicaciones de académicos y participación de los mismos en encuentros nacionales e internacionales.

Ha sido una riqueza de la revista el interés de los estudiantes por publicar en sus páginas, por lo cual se creó una sección Artículos de estudiantes. Los primeros estudiantes articulistas aparecen en el $\mathrm{N}^{\circ}$ 10 de 1999, y fueron Adán Salinas, Gonzalo García, Ramón Curivil y Claudio Pinto. En el número siguiente escriben Cristián Valdés, Martín Ríos, Rodrigo Segovia y Martín Lasserre. Incluso, varios de los académicos actuales de la Escuela de Filosofía publicaron sus trabajos cuando eran estudiantes.

En este marco, hubo también dos proyectos de revistas de filosofía gestionados por estudiantes. Uno de estos proyectos fue Horos, liderada por Juan Henríquez, y la más reciente Exterioridad, a cargo de Javier Gatica y Alonso Muñoz.

Los académicos de la carrera de Filosofía han participado siempre en la revista con sus artículos y reseñas. También han sido numerosos los aportes de académicos de universidades chilenas y de otros países. De ello dan cuenta los Índices de Autores, publicados en los números 13 y 27.

Todos estos antecedentes dan cuenta del esfuerzo editorial que ha implicado la revista a través de 30 años y de su mejoramiento en el contenido, el diseño, periodicidad (dos números al año) y la gran apertura a los temas actuales, así como del interés de académicos pertenecientes a otras universidades nacionales y extranjeras por colaborar con sus artículos e investigaciones. 